\title{
PSYCHOLOGY
}

\section{ПСИХОЛОГІЧНЕ ЗАБЕЗПЕЧЕННЯ СОЦІАЛЬНОӦ ПІДТРИМКИ РОЗВИТКУ ПРОФЕСІОНАЛІЗМУ ФАХІВЦІВ}

\author{
здобувач кафедри психології та сочіології Бабатенко О. В. \\ Україна, Сєвєродонецьк, Східноукраїнський наџіональний університет імені Володимира Даля
}

DOI: https://doi.org/10.31435/rsglobal_ijitss/30092019/6671

\section{ARTICLE INFO}

Received 19 July 2019

Accepted 16 September 2019

Published 30 September 2019

\section{KEYWORDS}

social systems, psychological state, specialists, food industry, methodical approach, social support, development.

\begin{abstract}
The article analyzes the peculiarities of psychological support of social support for the development of professionalism of specialists in the food industry. Purpose of the article was to determine the peculiarities of the optimization factors of the functional state of food industry professionals in the annual cycle of activity for psychological support of social support for the development of their professionalism. The methodological approach is based on theoretical and methodological provisions on the systemic structure of mental phenomena and the concept of the development of socio-technical systems of activity. Empirical methods of research were used: conversation, observation, questioning, expert evaluation, analysis of the results of activity, psychological experiment (conceptual and formative); psychodiagnostic methods (estimation of solving problems with a computer (by O. Sheviakov), studying memorization of fivedigit numbers with subsequent reproduction (by R. Amthauer), concentration of attention on M. Anfimov's corrective attempt, rings and entangled lines Landolt, distribution of attention on the red-black table K. Platonov, self-assessment of the subjective state by the method of "Feeling-Activity-Mood (FAM)" V. Doskin, psychophysiological (critical frequency of fusion of light flashes), latent periods of simple sensations (LP Methods of arbitrary mental regulation of functional state (autotraining, ideomotor training).
\end{abstract}

Citation: Бабатенко O. B. (2019) Psykholohichne Zabezpechennia Sotsialnoi Pidtrymky Rozvytku Profesionalizmu Fakhivtsiv. International Journal of Innovative Technologies in Social Science. 6(18). doi: 10.31435/rsglobal_ijitss/30092019/6671

Copyright: (C) 2019 Бабатенко О. В. This is an open-access article distributed under the terms of the Creative Commons Attribution License (CC BY). The use, distribution or reproduction in other forums is permitted, provided the original author(s) or licensor are credited and that the original publication in this journal is cited, in accordance with accepted academic practice. No use, distribution or reproduction is permitted which does not comply with these terms.

Вступ. Наукова проблема полягає в тому, що в дослідженнях психологічних станів фахівців харчової промисловості немає чіткого розуміння ролі і змісту психологічного забезпечення соціальної підтримки. Отримання достовірної інформації про соціальну підтримку знижує рівень негативних психологічних станів і дозволяє фахівцям в найкоротші терміни пристосуватися до нових організаційних змін.

Аналіз останніх досліджень і публікацій. В харчовій промисловістю значна частина професій пов'язана з виконавською діяльністю. Успішність функціонування соціотехнічних систем зумовлюється багатьма чинниками, одним із яких є показник працездатності людини. Найбільш складним завданням, яке стоїть сьогодні перед дослідниками (перш за все соціальними психологами та соціальними робітниками), є вироблення критеріїв, за допомогою яких можливо було б визначити рівень працездатності та безпечної діяльності фахівців. Тому одним 3 таких критеріїв може бути критерій функціонального стану (ФС) організму, який можна отримати у вигляді інтегрального показника [1]. Розвиток теорії, методів та практики вивчення ФС людини, що виникають в процесі професійної діяльності, є важлива умова оптимізації праці, підвищення іiі ефективності, надійності та якості. Формування таких негативних станів як перевтома, монотонія, 
емоційна напруженість, різні форми стресових реакцій призводять до збільшення кількості помилкових та неправильних дій, підвищення розвитку професійних захворювань тощо. В зв'язку з цим в соціальній психології проблемі вивчення станів людини в умовах професійної діяльності приділяється особлива увага. При цьому вона розглядається вченими як основа для вирішення таких важливих практичних завдань, як психологічне забезпечення надійності функціонування соціотехнічних систем і збереження фізичного та психічного здоров'я фахівців, формування готовності до професійної діяльності [2].

Потреба в використанні психопрофілактичних заходів для оптимізації ФС в харчовій промисловості досить значна, оскільки діяльність фахівців проходить в умовах змін соціальнопсихологічних, технічних, природних та інших чинників, які призводять до зниження рівня працездатності.

Мета статті: визначити особливості оптимізаційних чинників функціонального стану фахівців харчової промисловості в річному циклі діяльності для психологічного забезпечення соціальної підтримки розвитку їх професіоналізму.

Гіпотеза дослідження: прийоми довільної саморегуляції психічного стану суттєво впливають на інтегральний функціональний стан фахівця і через це на якісні та кількісні психологічні та психофізіологічні характеристики його діяльності.

Завдання дослідження:

1. Провести теоретичний аналіз існуючих напрямів вивчення функціонального стану в комплексі наук про професійну діяльність людини.

2. Розробити психограму діяльності фахівців харчової промисловості і на її підставі обгрунтувати комплекс діагностичних методик, адекватних змісту праці останніх.

3. Провести психодіагностику та корекцію негативних функціональних станів фахівців, що виникають в умовах професійної діяльності впродовж одного року.

4. Розробити практичні рекомендації для оптимізації несприятливих функціональних станів в умовах організаційних змін професійної діяльності.

Методологію дослідження склала концепція психологічного забезпечення розвитку соціотехнічних систем, логіка представлення дослідженого матеріалу поєднала теоретичну ідею розвитку системи діяльності фахівців харчової промисловості 3 емпіричними дослідженнями динаміки їх функціонального психологічного стану.

Результати дослідження. Спираючись на ідеї про розвиток соціотехнічних систем діяльності [3], розглянемо систему діяльності фахівця як процес, що складається 3 чотирьох компонентів: інтенційного («спонукаючого»), операційного («технологічного»), активаційнорегуляторного (емоційно-вольова регуляція процесу діяльності) і базового (психофізіологічні функції). 3 цих компонентів формується професійно зумовлена конкретна цільова система діяльності. Вона складається з чотирьох підсистем. Перша - підсистема зовнішньої взаємодії $з$ соціумом, яка забезпечує вибір мети діяльності, формулювання завдань і реалізацію процесу досягнення мети шляхом опосередкованої взаємодії з предметом діяльності Друга підсистема психологічного забезпечення функціонування. Ця підсистема також працює за цільовим принципом, але метою у даному випадку є підтримка працездатності, забезпечення необхідних психофізіологічних констант при різних впливах соціуму. Третя підсистема умовно названа спонтанною інформаційною активністю. Мова йде про те, що функції психіки людини проявляються у двох різних формах: цільовій активності, що ініціюється певними мотивами, котрі усвідомлено опредмечуються за конкретних умов. Четвертою підсистемою $\epsilon$ інтегральний регулятор активності, котрий забезпечує об'єднання всіх підсистем до єдиної системи діяльності.

Концепція психологічного забезпечення функціонування лежить в основі всіх теоретичних положень та практичних методів нашого дослідження. Психологічне забезпечення розвитку соціотехнічної системи спрямоване на розвиток іiї властивостей в ході проектування, функціонування та вдосконалення (модернізації), а також властивостей заходів, методів та засобів формування та підтримання необхідних професійних якостей і функціонального стану фахівців, тобто розвиток системи формування та підтримання працездатності.

Для конкретного дослідження в рамках даної роботи ми обрали високоавтоматизовану соціотехнічну систему діяльності фахівця харчової промисловості. Вона виокремлена на основі аналізу системи діяльності фахівців сучасних підприємств.

Для формування необхідного рівня працездатності використовувались формувальнорозвивальні методи засвоєння прийомів довільної психічної саморегуляції (нервової релаксації, ідеомоторного тренування, аутотренінгу). Кінцевою метою програми використання формувально-розвивальних методів було формування та розвиток навичок довільної психічної 
саморегуляції для зняття симптомів професійної втоми та емоційної напруги в кінці зміни і мобілізації внутрішніх ресурсів перед роботою.

Навчання фахівців за цією програмою проводилось впродовж двох місяців у формі соціально-психологічного тренінгу.

Основу для визначення особливостей динаміки працездатності фахівців харчової промисловості склали результати психодіагностичного обстеження останніх в умовах діяльності впродовж одного року.

Організаційно робота для дослідження психофізіологічного стану фахівців була проведена в три етапи. На першому етапі було з'ясовано особливості динаміки показників функціонального стану $(Ф С)$ та визначено розбіжності між ними. На підставі отриманих даних встановлено, яка бригада $\epsilon$ найбільш несприятливою 3 точки зору максимальних зрушень основних психодіагностичних показників та інтегрального показника ФС.

На першому етапі в експерименті брало участь 150 фахівців, які досліджувались впродовж одного місяця при роботі в різні зміни. Порядок та організація досліджень забезпечили послідовне обстеження їх при роботі в першу, другу і третю зміни. Дослідження кожної зміни проводилось впродовж одного тижня за методиками визначення суб'єктивного відображення стану (САН, опитувальник Спілбергера-Ханіна); методикою визначення побічних показників працездатності (слухова пам'ять, зорова пам'ять, коректурна проба, КЧЗСМ, усний рахунок, продовження числових рядів); методики визначення прямих показників працездатності), що дало змогу отримати усереднені дані за кожну зміну.

На підставі результатів дослідження, отриманих за всією вибіркою досліджуваних та повторних тестувань для кожного фахівця в найбільш сприятливі періоди, були отримані зони оптимальних значень для кожного діагностичного показника та визначені фонові показники, відповідно до яких розраховувались інтегральні значення для кожного із «зрізів» ФС. Значення інтегральних показників для кожного «зрізу» ФС розраховувались за наступною формулою:

де $\quad \mathrm{i}-$ інформативні показники;

$$
\gamma=\frac{1}{\mathrm{n}} \sum_{\mathrm{i}=1}^{\mathrm{n}} \frac{\mathrm{Xi}-\mathrm{X} \phi}{\mathrm{Ximax}-\mathrm{X} \phi}
$$

$\mathrm{n}$ - число інформативних показників;

$\mathrm{Xi}$ - оцінка і-го показника в конкретному випадку;

Хімах - мода діапазону оптимальних значень для і-го показника

Хф - фонові значення для і-го показника.

При порівняльному аналізі результатів обстежень виявлено, що найбільш суттєві відмінності між показниками ФС від початку до кінця роботи мають місце для фахівців третьої зміни. Зрушення основних показників професійно-важливих функцій цієї зміни складають 16-18\% в порівнянні з тими, що оцінювались перед початком роботи, тоді як аналогічні зрушення для відповідних показників перших двох змін складають 12-14\%. Достовірність відмінностей між зрізами ФС, отриманих до початку та після зміни, за всіма показниками оцінювалось за допомогою критерію t-Стьюдента (з $\mathrm{P} \leq 0,05)$, яка виявилась статистично значима для більшості діагностичних показників фахівців третьої зміни. При порівняльному аналізі отриманих результатів дослідження всіх бригад виявлено, що третя зміна $€$ найбільш несприятлива з точки зору максимальних зрушень основних психодіагностичних показників та ступеня їх вираженості і визначена нами для додаткового обстеження впродовж одного року 3 метою виявлення особливостей динаміки працездатності фахівців, розробки та реалізації відповідних оптимізаційних процедур.

Аналіз інтегральних показників часткових функцій та інтегрального показника ФС в цілому свідчить про те, що тільки перед початком роботи більшість інформативних показників (за виключенням емоційної напруженості), належать до зони оптимальних значень, хоча і вони не досягають фонових, а значення інтегрального показника ФС в цілому оцінюється як оптимальне.

Оцінка інтегральних показників ФС в кінці роботи свідчить про те, що значення всіх інформативних показників зміщуються в зону негативних значень і виходять за межі оптимальних. Загальна тенденція до зрушень показників в негативний бік зберігається за всіма показниками, однак показники оперативної пам'яті, критичної частоти злиття світлових миготінь (КЧЗСМ) та суб’єктивної оцінки стану зазнають найбільших зрушень. У змістовному плані глибина зрушень основних інформативних показників свідчить про те, що в кінці зміни формується несприятливий ФС, пов'язаний зі зниженням ефективності діяльності і у фахівців третьої зміни має більш чітко виражений характер і може бути кваліфікований як стан гостро вираженої втоми.

На другому етапі експериментального дослідження здійснювалась оцінка динаміки працездатності фахівців третьої зміни, що було необхідною умовою для визначення головних 
тенденцій в зміні ФС та ступеню вираженості його основних зрушень. Для вирішення цього завдання проведено діагностичне обстеження в річному циклі діяльності. Для оцінки змінної динаміки працездатності фахівців харчової промисловості в річному циклі дослідження всі діагностичні показники були приведені до єдиної системи виміру, що дозволило розрахувати інтегральні показники як часткових функцій, так і ФС в цілому. За допомогою цієї ж формули розраховувались значення інтегральних показників для часткових функцій, які належать до одного рівня прояву ФС. Це дало змогу одночасно простежити спрямованість та ступінь вираженості відхилень основних проявів ФС відносно фонового рівня, який визначено нами за нульовий. Аналіз отриманих результатів та їх динаміка свідчать про те, що в динаміці працездатності фахівців в річному циклі дослідження, достатньо обгрунтовано розрізняються ФС (рис.1), які відповідають періодам впрацювання, оптимальної та нестійкої працездатності.

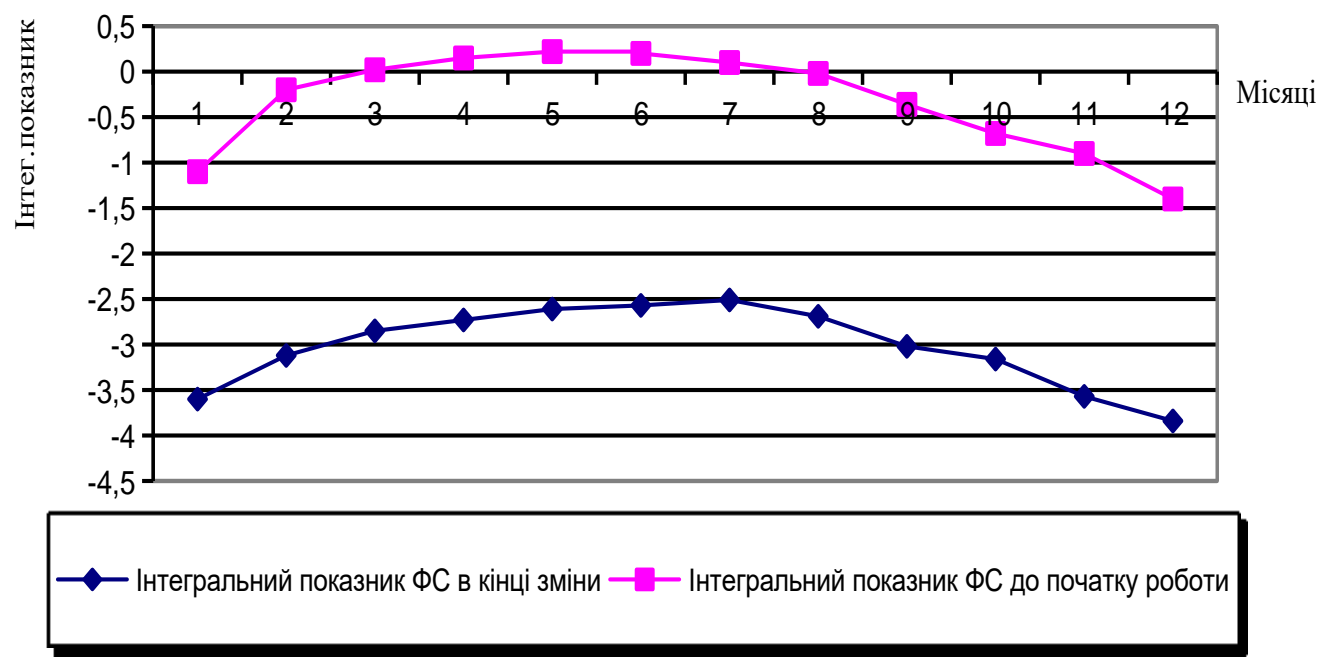

Рис.1. Динаміка інтегрального показника ФС фахівців харчової промисловості в річному цฺиклі діяльності

Період впрацювання (до 3-х місяців) характеризується тенденцією до зрушення більшості оцінок в сторону позитивних значень, зворотна залежність виявлена тільки для КЧЗСМ. Однак, незважаючи на позитивну динаміку з боку більшості показників ФС, більшість їхніх значень достовірно відрізняються перед початком роботи та наприкінці зміни. Слід зазначити, що інтегральні оцінки ФС фахівців впродовж всього періоду впрацювання як до початку роботи, так і в кінці зміни не перевищують фонові показники. Аналіз динаміки інтегральних показників ФС на етапі впрацювання дає змогу виявити тенденцію до зміни останніх в бік фонових значень. В цілому ж між частковими показниками ФС спостерігається узгоджена динаміка, хоча вже перед початком роботи ряд показників, зокрема значення інтегральних показників слухової, оперативної пам'яті, швидкості переробки інформації мають найнижчі оцінки, в той час як показники суб'єктивної оцінки стану наближаються до фонових. Незважаючи на деякі розбіжності в оцінках серед часткових показників, всі вони, за виключенням реактивної тривожності, перед початком роботи належать до зони оптимальних значень. Аналіз динаміки інтегральних показників ФС в кінці роботи впродовж всього періоду впрацювання показує, що спостерігається тенденція до зрушення всіх показників в бік негативних значень, а глибина зрушень останніх від початку до кінця роботи складає 15-20\%. Серед інформативних показників найбільших зрушень зазнають значення суб’єктивної оцінки стану, оперативної пам’яті та КЧЗСМ. Зазначені тенденції підтверджуються проведенням кореляційного аналізу з обчисленням коефіцієнта рангової кореляції Спірмена. Стійкі позитивні кореляційні зв'язки спостерігаються між показниками психофізіологічного, операціонального забезпечення діяльності та суб'єктивної оцінки стану (r не менше $+0,66)$, слабкі позитивні зв'язки відмічаються між показниками професійного рівня та емоційною напруженістю (r не більше +0,28), що підтверджує узгодженість в динаміці останніх.

Таким чином, період оптимальної працездатності фахівців третьої зміни перед початком роботи характеризується стабільністю, так як більшість діагностичних показників, за виключенням оперативної пам'яті, належать до зони оптимальних значень. ФС фахівців в кінці зміни визначається як несприятливий і зумовлюється зрушеннями інформативних показників в бік негативних значень. Визначені закономірності в динаміці показників, глибина їх зрушень, розрахунки інтегрального показника ФС, дають можливість стверджувати, що в кінці зміни у фахівців розвивається гостра втома, а функціонування організму відбувається із залученням резервних та компенсаторних механізмів, що забезпечує підтримання діяльності з необхідною ефективністю. 
В межах розвитку системи формування і підтримання працездатності на стадії експлуатації соціотехнічної системи досліджено особливості формування необхідного рівня працездатності фахівців в умовах харчової промисловості. Обгрунтовано необхідність оволодіння навичками саморегуляції, виходячи з необхідності діяти відповідно до особливостей виробничої ситуації.

Робоча гіпотеза дослідження була сформована у такий спосіб: ми припускали, що впровадження прийомів довільної психічної саморегуляції в процес діяльності фахівців буде ефективним 3 погляду формування і підтримки необхідного рівня їх працездатності за пріоритетними показниками ФС.

Для розуміння природи формування ФС проведено факторний аналіз (ФА) отриманих даних за всією вибіркою в річному циклі дослідження. При ФА інформативних показників ФС операторів до початку роботи отримані наступні результати: із факторів, які впливають на інтегральний показник ФС виділяються два, факторне навантаження яких більше за одиницю. Причому особливого значення набуває перший фактор F1 $(6,020)$, значення якого в п'ять разів перевищує факторне навантаження другого фактору F2 $(1,155)$. Розрахунковий показник значимості двох факторів складає 78\% від загальної сукупності факторів, що достатньо для подальшого аналізу.

До першого фактору (психофізіологічного та операціонального забезпечення) до початку роботи відносяться змінні: швидкість переробки інформації, оперативна пам'ять, усний рахунок та критична частота злиття світлових миготінь; до другого (суб'єктивного стану та професійного рівня операторів) - реактивна тривожність, САН, слухова пам'ять та прямі показники працездатності. В кінці зміни перший фактор визначається лише підсистемою психофізіологічного забезпечення (слухова пам'ять, КЧЗСМ, усний рахунок та швидкість переробки інформації).

Другий фактор залежить від підсистем операціонального забезпечення, суб'єктивної оцінки стану та показників професійного рівня (реактивна тривожність, суб'єктивна оцінка стану, оперативна пам'ять та прямі показники працездатності), що підтверджує наявність різноспрямованих тенденцій в кінці зміни. При вивченні особливостей динаміки працездатності фахівців було встановлено, що до кінця зміни в останніх розвивається гостра втома, яка може призвести до перевтоми; в цьому плані працівники третьої зміни складають групу “ризику”, в яких вона може розвинутися в першу чергу. Характер змін, що спостерігалися при зрушеннях діагностичних показників, склали основу для проведення роботи щодо оптимізації та профілактики несприятливих ФС.

Основу для проведення порівняльного аналізу склали результати дослідження експериментальної групи фахівців, які виявили бажання навчатися за спеціальною методикою психорегулюючого професійного тренінгу, тобто експериментальна група була сформована на добровільних засадах без додаткових критеріїв відбору. Заняття поводились тричі на тиждень у вечірній час впродовж 30 хвилин. Діагностичні обстеження проводились щомісяця за 1-1,5 години до початку роботи та зразу в кінці зміни.

Таким чином, проведена дослідницька робота щодо вивчення та аналізу змінної динаміки працездатності фахівців харчової промисловості, виявлення особливостей прояву їх ФС на різних етапах професійної діяльності дала можливість перевірити і підтвердити запропоновані моделі та гіпотези.

Висновки. Теоретичний аналіз існуючих напрямів вивчення функціонального стану (активаційно-енергетичного, суб‘ єктивних переживань, кількісних i якісних показників результативності діяльності) показав, що використання теоретичної та методичної бази кожного 3 них $\epsilon$ недостатнім для оцінки та регуляції функціонального стану. Тому використання комплексного підходу до оцінки функціональних станів 3 позиції соціотехнічних уявлень про їх природу, створює умови для своєчасної діагностичної (контроль, оцінка) та корекційної (оптимізація, профілактика) роботи в умовах професійної діяльності. Зазначений підхід грунтується на теоретико-методологічних положеннях про системну будову психічних явищ. Перспективи подальших досліджень полягають у науковому обгрунтуванні методики формування та підтримання необхідного рівня працездатності фахівців на всіх етапах циклів функціонування та розвитку соціотехнічних систем діяльності.

\section{ЛІТЕРАТУРА}

1. Бодров В.А. Работоспособность человека-оператора и пути ее повышения. Психологический журнал. 1997. 8:107-118.

2. Корольчук М.С. Шляхи та заходи психофізіологічного забезпечення професійної діяльності. Матеріали конференції УВС МВС. 1995:64-67.

3. Шевяков А.В., Хасхачих Е.Г. Динамика функционального состояния операторов-металлургов при различном качестве дисплейных видеокадров. Физиология человека. 1994. 30 (4):76-82. 